\title{
Konfigurasi Kepemimpinan Nasional Perspelktif Pluralisme Agama di Indonesia
}

\author{
Yusdani
}

The public election 2004 denotes the moment of history for developing future Indonesia. In this sense, the public election can be called as a chance to end the national leadership crisis. The succession of national leadership and in order to Indonesian people choose national leader who including qualification and able to bring this nation toward change. For that reason, it is imporiant to formulate the criteria of national leader. Because of Indonesia nation is pluralistic nation either in term of religion, cultural background or etc. So that, the national leader that Indonesian people need is inclucive, pluralist and dialogist leader.

6 ejak pemerintahan Habibie hingga pemerintahan Megawati-Hamzah Haz sekarang ini dianggap telah gagal mewujudkan cita-cita reformasi, yaitu memberantas korupsi, kolusi dan nepotisme. Bahkan, penguasa sekarang ini, dinilai oleh sementara pihak justru tidak lebih baik jika dibanding dengan pemerintahan Orde Baru. Penilaian seperti itu muncul karena melihat indikasi berbagai kebijakan pemerintah sekarang ini yang tidak mengakomodasi aspirasi rakyat. Atas dasar itu, ada ,ndikasi kuat dari semua elemen bangsa, terutama elit parpol untuk mengadakan perubahan untuk melakukan pergantian kepemimpinan nasional.

Untuk menyongsong perubahan dan pergantian kepemimpinan nasional di atas dan agar rakyat dapat memilih pemimpin yang memenuhi kualifikasi dan mampu membawa bangsa ini ke arah perubahan, maka diperlukan formulasi kriteria pemimpin bangsa. Dengan kriteria yang dimaksud diharapkan pemimpin bangsa yang terpilih pasca pemilu 2004 akan dapat membawa bangsa ini keluar dari krisis multidimensi.

Pemilu 2004 merupakan momen historis penting bagi perjalanan bangsa Indonesia di masa depan. Pesta demokrasi tersebut dapat disebut sebagai peluang mengakhiri krisis kepemimpinan nasional yang parah, yang dengannya agendaagenda besar reformasi diharapkan dapat terealisasikan dengan baik. Sudah tentu pascapemilu bangsa Indonesia bukan saja mengharapkan pergantian kepemimpinan nasional secara legal-konstitusional, karena pemimpin yang kini berkuasa tidak dapat diharapkan memunculkan perubahan berarti bagi segenap elemen bangsa. Namun lebih dari itu, dalam Pemilu 2004 bangsa Indonesia juga membutuhkan pergantian kepemimpinan nasional yang nantinya dapat mewujudkan terciptanya kesejahteraan dan keadilan bagi semua. ${ }^{1}$

1 Asmar Oemar Saleh, "Kriteria Presiden Masa Depan", dalam Republika Rabu, 15 Oktober 2003 (opini), h/m.4. 
Bangsa Indonesia memang telah mengalami pergantian kekuasaan beberapa kali, namun para pemimpin tersebut gagal mentransformasikan segenap kapabilitas mereka untuk kebaikan negeri tercinta ini. Para pemimpin pasca-Soeharto cenderung sibuk dengan kepentingan dan sembari mengabaikan kepentingan khalayak hingga membuat rakyat kecewa berat. Ketidakpuasan publik terhadap para penyelenggara negara tersebut diwujudkan dengan beragam cara: dari demonstrasi damai, munculnya gejala "emoh" (partai) politik, meruyaknya kekerasan di banyak tempat, dan yang paiing mencemaskan adalah lahirnya wabah "SARS": Sindrom Aku Rindu Soeharto. Berbagai simptom tersebut membersitkan kesan kuat bahwa sebagian masyarakat sudah sampai pada satu titik yang mengkhawatirkan, yaitu putus asa. ${ }^{2}$

Rakyat yang menghajatkan masa lalu hadir kembali tentu saja tidak dapat dipersalahkan. Soalnya rakyat sudah terlalu berbaik hati kepada para pemimpin yang menindas rakyat. Kerinduan terhadap masa lalu yang secara simbolik direpresentasikan dengan hadirnya Soeharto merupakan konsekuensi logis tidak berhasilnya pemimpin pasca-Soeharto memenuhi kebutuhan konkret rakyat. Menyalahkan rakyat hanya akan membuat bangsa Indonesia jatuh pada logika blamming the victims, menyalahkan korban. Rakyat adalah korban dari absennya political will penyelenggara negara dalam mengentaskan bangsa dari krisis multidimensional. Anggaplah pemimpin pasca-Soeharto Habibie, Abdurrahman Wahid, dan Megawati - sebagai pemimpin masa lalu seperti Soeharto. Jika Soeharto menciptakan krisis multidimensional, para pemimpin pascaSoeharto tersebut mengawetkan krisis tersebut dan tidak tergerak mengenyahkannya secara tuntas. Pengalaman berharga ini hendaknya tidak membuat bangsa indonesia bernasib seperti keledai: terperosok pada lubang yang sama. Masyarakat harus lebih cerdas, arif, dan rașional dalam memilih presiden dalam pemilu nanti. Pasalnya nasib rakyat amat ditentukan oleh tepat tidaknya pilihan rakyat sendiri. ${ }^{3}$

\section{Formulasi Kriteria Pemimpin Bangsa}

Sebagai upaya untuk memberikan pendidikan politik kepada seluruh komponen bangsa, resep perbaikan kualitas berbangsa adalah perbaikan kualitas pemerintahannya. Mengingat persolan-persoalan yang dihadapi bangsa ini, sebagai sebuah bangsa yang berkembang, adalah persoalan yang selalu terkait dengan pemerintahan yang kurang populer di mata rakyatnya, kurang berpihak pada rakyat, korup dan bahkan menganiaya rakyat. Perbaikan kualitas pemerintahan dapat ditempuh dengan cara menerapkan prinsip pemerintahan yang bersih melalui proses pemerintahan yang baik (good governance). Karena itu, persoalan pergantian kepemimpinan nasional dan perumusan kriterianya merupakan prasyarat untuk terbentuknya suatu pemerintahan yang bersih melalui pemerintahan yang baik dan good governance dapat dijalankan dengan dasar transparency, responsibility, accountability, participation, dan responsiveness. ${ }^{4}$

Sebagai gambaran awal, beberapa kriteria penting yang harus dimiliki oleh presiden Indonesia di masa depan

${ }^{2}$ Ibid.

${ }^{3}$ Ibid.

"Mardiasmo, "Sistem Pengukuran Kinerja Sektor Publik: Telaah Kritis Terhadap Kebutuhan Pengukuran Kinerja Pemerintah Daerah", dalam Jumal /lmu-/lmu Sosial Unisia No.46/XXV/ili/2002, hlm. 311. 
(pascapemilu 2004), antara lain, memiliki integritas di atas rata-rata rakyat yang dipimpinnya, kapasitas kecendekiawanan, memiliki kemampuan berkomunikasi secara baik kepada publik yang dipimpinnya, visi merupakan hal tak terelakkan yang harus dimiliki oleh seorang pemimpin, berpaham inklusif, memiliki kemampuan - managerial leadership bangsa, mempunyai visi reformis, memliki komitmen kerja keras dalam mengentaskan krisis multidimensi yang sedang melanda bangsa ini, memahami dan mampu menyelami aspirasi dan keinginan rakyat, dan dapat merangkul dan mengakomodasi sisi pluralitas (kemajemukan) karena kondisi bangsa Indonesia memang beragam.

Dari beberapa kriteria tersebut, nampaknya pemimpin yang memiliki paham inklusif-pluralis perlu mendapat porsi perhatian yang besar. Hal ini dikarenakan bangsa Indonesia diperjuangkan bukan saja oleh kalangan tertentu saja, melainkan oleh segenap anak bangsa. Bangsa Indonesia pun terdiri dari beraneka ragam suku, agama, dan ras. ${ }^{5}$ Karena itu pemimpin yang cocok memimpin negeri ini adalah orang yang memiliki komitmen dan penghormatan terhadap pluralitas, dan menyadari sepenuhnya bahwa bangsa ini tidak mungkin diatur dengan menganakemaskan atau menganaktirikan satu golongan tertentu saja.

Dengan demikian eksklusivisme tidak boleh mendapat tempat dalam kepemimpinan nasional. Bangsa ini tidak menginginkan bangsa ini diatur oleh pemimpin berwawasan picik sempit yang hanya mementingkan satu unsur saja, baik berdasarkan agama, ras, suku, atau golongan tertentu. Sebagai satu bangsa, satu tubuh, maka kita menghendaki semua anak bangsa dapat hidup nyaman dalam rumah besar Indonesia. Beragam suku, etnik, agama, dan golongan merupakan sunnatullah yang tidak boleh ditampik. Karena itu pemimpin yang baik adalah yang dapat menyantuni pluralitas tersebut dan tidak meminggirkannya. Sesungguhnya menyantuni dan menghormati pluralitas merupakan wujud ketaatan terhadap ketetapan sunantullah tersebut.

Negara yang mengubah sistem politik dari menerima plutalitas ke pendasaran pada suatu agama, suku, budaya tertentu berarti mengubah pemahaman akan konsep bangsa. Bangsa merupakan bentuk politik dari modernitas. Modernitas mengandaikan adanya pengembangan tradisj-tradisi, kebiasaan-kebiasaan dan hak istimewa menjadi sesuatu yang mempunyai kepentingan lingkup nasional. Pengembangannya diarahkan pada hukum yang mendasarkan pada prinsip akal budi. Definisi bangsa demikian ini mengandaikan

5 Sebagai pendukung periunya pemimpin Indonesia yang pluralis karena secara empirik dan sosiologis Indonesia adalah salah satu bangsa pluralis. Dengan 17.000 pulau yang ada di wilayahnya, baik yang besar-maupun kecil, baik yang dihuni maupun yang tidak, Indonesia juga adalah negara kepulauan, dan negara dengan latar belakang yang paling beraneka ragam. Dengan sekitar 400 kelompok etnis dan bahasa yang ada di bawah naungannya, Indonesia juga adalah sebuah negara dengan kebudayaan yang sangat beragam lihat Nurcholish Madjid,.1998." Mencari Akar-Akar Islam Bagi Pluralisme Modern :Pengalaman Indonesia", dalam Mark R.Woodward (Ed.). Jalan Baru Islam Memetakan Paradigma Mutakhir Islam Indonesia terjemahan dari jududl asli Toward $A$ New Paradigm : Recent Developments in Indonesian Islamic Thought oleh Ihsan Ali - Fauzi. Bandung: Mizan, hlm.91. Dilihat dari sisi kepercayaan agama, Bangsa Indonesia menganut agama yang beragam, yaitu Islam, Kristen Proetestan, Kristen Katholik, Hindu, Budha, dan lain-lain. 
memudarnya bentuk-bentuk ikatan primordial dan menekankan pada rasionalitas. Pemahaman bangsa seperti ini membuka setiap orang untuk ambil bagian di dalam pengembangan bangsa tersebut. Tidak ada kelompok yang dinafikan atau dimarjinalisasikan karena alasan ideologi, agama, budaya, dan suku tertentu. ${ }^{6}$

Dalam masyarakat yang plural tuntutan teokrasi berlawanan dengan konsep bangsa. Konsep bangsa mengandaikan, pertama, adanya acuan ke budaya yang sama, dalam arti suatu sistem gagasan, tanda, dan cara bertindak dan berkomunikasi. Tuntutan ini tidak mungkin dipenuhi kalau bahasa yang menjadi alat legitimasi hanya dikuasai oleh kalangan elite terbatas dan budaya yang menjadj dasar kekuasaan merupakan milik kelompok tertentu saja. Dalam hal ini, belum tentu orang-orang yang seagama akan setuju bahwa agamanya dijadikan landasan sistem politik bagi semua. Kedua, bangsa merupakan bangunan keyakinan, loyalitas, dan solidaritas anggota-anggotanya. Bila legitimasi kekuasaan berdasar atas agama tentu sebagian masyarakat sudah dengan sendirinya dinafikan, perandaian solidaritas itu tidak ada maknanya. Ketiga, bangsa terbentuk bila anggota-anggota masyarakat saling mengakui hak-hak dan kewajibankewajiban masing-masing karena status mereka sama. Tuntutan ini tidak mungkin dipenuhi dalam negara teokrasi, karena pemeluk agama-agama lain praktis tidak mempunyai hak dan kewajiban yang sama alias menjadi warga negara kelas dua. Mungkin dilindungi, tetapi tidak mempunyai hak yang sama, apalagi akses ke kekuasaan. Dengan demikian, bangsa menuntut bentuk organisasi sosial yang didasarkan pada budaya yang inklusif serta menghargai status dan hak individu. Tekanan kebijakan pada citizenship daripada kelompokkelompok kepentingan lebih menjamin perlindungan terhadap hak-hak asasi warganegara. ${ }^{\text {? }}$

\section{Islam dan Kepemimpinan Bangsa.}

Dalam konteks bangsa Indonesia yang plural seperti tersebut di atas, perlu dikembangkan gagasan - bahwa Islam sebagai faktor komplementer kehidupan sosial-budaya dạn politik Indonesia. ${ }^{8}$ Dengan demikian, upaya untuk melakukan sintesa Islam dan negara di Indonesia, komunitas Islam untuk tidak memperlakukan Islam sebagai sebuah ideologi alternatif. Bertitik-tolak dari pandangan ini, sebagai komponen utama dalam struktur sosial masyarakat Indonesia, Islam hendaknya tidak diletakkan secara berhadap-hadapan dengan komponenkomponen lain. Sebaliknya, Islam harus diposisikan sebagai faktor komplementer dalam pembentukan struktur sosial, budaya dan politik Indonesia. Karena karakter komunitas sosial, budaya, dan politik nusantara yang heterogen, usaha untuk menempatkan Islam sebagai "pemberi warna tunggal" hanya akan menghantarkan Islam sebagai faktor divisive. ${ }^{9}$

Pemikiran tersebut di atas tidak berari menghalang-halangi Islam untuk memainkan peran dalam negara. Yang menjadi perhatian dalam kaitan ini adalah adanya peran yang sama bagi setiap kelompok agama di tengah kehidupan berbangsa dan bernegara. Untuk itu, kendatipun kurang tepat mengembang-

$\therefore$

- Haryatmoko, Etika Politik dan Kekuasaan.( Jakarta: Kompas,2003), hlm. 199-200.

${ }^{7}$ lbid, him.200-201.

${ }^{8}$ Abdurrahman Wahid, "Massa Islam dalam Kehidupan Bernegara dan Berbangsa", dalam Prisma, Edisi Extra, 1984,'hlm.3-9.

${ }^{9}$ lbid. hlm.8 
kan gagasan "Islam sébagai pemberi warna tunggal," tetapi masyarakat Muslim mempunyai hak yang sama untuk mengisi kehidupan berbangsa dan bemegara dengan nilai-nilai ajaran agamanya. ${ }^{10}$

Sejalan dengan pemikiran di atas, dengan segala kelemahan dan kekurangannya, muslim Indonesia sejak masa pergerakan nasional sudah memilih sistem politik demokrasi sebagai wahana yang terbaik untuk membumikan cita-cita kemerdekaan. Pilihan ini dapat dinilai sebagai pilihan terbaik, tepat, dan benar. Oleh karena itu, organisasi-organisasi sosiokeagamaan dan sosio-politik Islam adalah sebagai pelopor utama bagi cita-cita demokrasi. Almarhum" partai Masyumi dikenal orang sebagai partai mati dalam keadaan syahid dalam membela dan mempertahankan demokrasi. Syahid dalam menghadapi sistem politik otoriter yang dipaksakan melalui mekanisme Demokrasi Terpimpin Orde Lama dan Demokrasi Pancasila Orde Baru yang dipaksakan beberapa puluh tahun silam.

Akan tetapi suatu hal yang memprihatinkan bahwa dalam sejarah politik bangsa Indonesia yang mayoritas muslim dan terkenal berbudaya santun itu dua kali peristiwa suksesi nasional - dari Orde Lama ke Orde Baru dan dari Orde Baru ke reformasi diwarnai pertumpahan darah, bahkan sekarang ini cenderung anarki dan disintegratif. Inilah salah satu akibat dan bahaya bangsa yang hidup dalam alam politik demokrasi yang semu dan jauh dari nilai-nilai moralitas dan etika politik kemanusiaan.

\section{Islam dan Cita-Cita Bangsa Indo- nesia}

Cita-cita bangsa Indonesia adalah membangun masyarakat Indonesia yang adil dan makmur. Adil dalam kemakmuran dan makmur dalam keadilan. Akan tetapi cita-cita untuk menciptakan tata sosial yang anggun dan hidup di bumi Indonesia yang adil tersebut perlu dicantolkan pada dasar etika transendental. Tanpa asas moral transendental yang kukuh ini jangan diharapkan bahwa keadilan menjadi cita-cita tersebut akan membumi.

Dari doktrin-doktrin di atas diharapkan akan mengalir prinsip-prinsip tentang keadilan, persamaan, persaudaraan, dan toleransi. Akan tetapi, doktrin yang tahan bantingan itu telah terkubur dalam abu sejarah selama berabad-abad dalam masyarakat dan peradaban umat Islam.

Penjelasan tentang cita-cita kemasyarakatan dalam perspektif di atas, menunjukkan bahwa ide yang begitu sentral tersebut telah memberikan ontologi bagi bangunan sebuah masyarakat dan peradaban yang hendak dibangun. Di atas landasan ontologi yang kuat, masyarakat yang hendak dibangun itu haruslah : terbuka, demokratik, toleran, dan damai. Empat ciri utama ini haruslah dijadikan acuan bagi semua gerakan pembaharuan moral dan masyarakat muslim di Indonesia ini. Umat Islam dalam konteks kepemimpinan nasional Indonesia amat mendambakan terwujudnya sebuah bangunan masyarakat yang berwajah ramah dan anggun. Dalam masyarakat dimaksud perbedaan agama, ideologi, dan nilai-nilai budaya, tidak boleh dijadikan penghambat untuk tercapainya cita-cita di atas.

Ciri keterbukaan tersebut berangkat dari argumen-argumen yang kuat, yaitu meneri-

${ }^{10}$ Abdurrahman Wahid, "Merumuskan Hubungan Ideologi Nasional dan Ajaran Agama", Aula Mei 1985,hlm.31. 
ma hakikat pluralisme agama dan budaya. Sikap yang harus dikembangkan bukan sikap "monopoli" kebenaran, tetapi sikap saling menghargai dan menghormati. Keterbukaan adalah watak dari sebuah perbedaan yang percaya diri. Sikap terbuka inilah pada masa lampau yang mendorong umat Islam berkenalan secara bebas dengan warisan ruhani hellenisme, Persia dan India. Adapun pada saat umat Islam telah kehilangan rasa percaya diri, sikap keterbukaan ini menjadi semakin redup. Kemudian paham persamaan dan menghargai pluralitas pasti punya dampak terhadap politik.

Masyarakat Islam haruslah mendukung berdirinya sebuah masyarakat yang demokratik. Sistem-sistem politik yang otoriter apa lagi yang totaliter harus dinyatakan sebagai sistem yang haram dalam perspektif tersebut, apapun alasannya. Hanya dalam sistem politik demokrasilah anggota masyarakat dapat mengembangkan potensi dirinya secara kreatif dan bebas sampai batas-batas yang jauh untuk menjadi manusia penuh.

: Dalam konteks dukungan terhadap sistem politik yang demokratis di atas, politik demokratis memerlukan toleransi. Tanpa toieransi sosial, manusia tidak mungkin dapat hidup aman dan damai. Dalam masalah toleransi ini, Islam boleh berbangga diri, khususnya terhadap kelompok nonmuslim. Dalam kasus ini, Islam normatif dan Islam sejarah seakan-akan telah menyatu. Hanyalah pada peristiwa-peristiwa sejarah yang tidak punya dampak besar sajalah umat Islam boleh jadi kurang menghiraukan budaya toleransi ini. Buku-buku sejarah banyak melukiskan ketinggian budi umat Islam dalam masalah tenggang rasa ini.

Akan tetapi yang ironis justru terletak pada kenyataan betapa terkadang sukarnya dikembangkan sifat toleransi internal di kalangan umat Islam sendiri, khususnya dalam politik. Di kawasan ini iklim psikologi umat memang sering rawan. Alangkah idealnya bila dalam masalah politik ini dibudayakan prinsip: "Berbeda dalam persaudaraan dan bersaudara dalam perbedaan"."

Ciri penting terakhir dari sebuah masyarakat plural ialah adanya jaminan damai dan terwujudnya kesejahteraan. Wajah-wajah yang mengerikan yang berlindung di balik label Islam adalah suatu pengkhianatan dan pencerobohan terhadap maksud Islam itu sendiri, Memperbaiki citra diri ini perlulah dijadikan program utama oleh seluruh gerakan Islam. Hanya sewaktu manghadapi musuh yang garang saja Islam perlu bersifat tegas dan pasti. ${ }^{12}$

\section{Islam dan Konfigurasi Kepemimpinan Nasional}

Perkembangan, prospek dan masa depan kepemimpinan Indonesia dalam era reformasi dan pasca pemilu 2004 akan membawa kepada berbagai implikasi. Khusus bagi perkembangan diskursus pemikiran dan praktek Islam itu sendiri. Untuk itu para pemikir, pemimpin dan aktivis politik Islam perlu (1) mereformulasikan dasar-dasar keagamaan/teologis ke dalam bidang politik secara cerdas; (2) mendefinisi ulang cita-cita politik; dan (3)merumuskan kembali strategi perjuangan politik Islam.

Faktor utama yang menyebabkan kemandekan politik di indonesia selama Orde Lama dan awal Orde Baru adalah keinginan para pemimpin politik Islam untuk

"Ahmad Syafi'i Ma'arif. Membumikan /sJam. (Yogyakarta: Pustaka Pelajar. 1995). HIm.70-71.

${ }^{12}$ Ibid, him. 71 
membangun hubungan Islam dan negara secara legal-formalistik. Oleh karena itu, dalam konteks Indonesia sekarang perlu dikembangkan pemikiran bahwa Islam lebih mementingkan terbentuknya sebuah tatanan masyarakat yang baik, yaitu masyarakat yang merefleksikan prinsip keadilan, egalitarianisme, partisipasi, musyawarah dan sebagainya. Sejauh mekanisme tatanan kemasyarakatan dan negara diatur dengan prinsip-prinsip dasar seperti itu, dapat dikatakan sebagai mekanisme dan sistem yang islami. ${ }^{13}$

Dengan demikian dasar-dasar baru politik yang dikembangkan lebih berorientasi pada terbentuknya sebuah sistem sosial dan politik yang merefleksikan nilai-nilai Islam. Karena prinsip-prinsip etis politik Islam berbicara tentang keadilan (adl), musyawarah (syura), persamaan (musawa), bentuk sistem kenegaraan yang secara substantif mencerminkan nilaj-nilai Islam adalah demokrasi.

Untuk itu, perumusan cita-cita politik dan kepemimpinan Islam masa depan di Indonesia berujung pada (1) terbentuknya mekanisme politik yang sifatnya egaliter dan demokratis; dan (2) berlakunya proses ekonomi yang lebih kurang equitable. ${ }^{14}$ Dalam kenyataan jalan untuk menuju Indonesia yarg demokratis dan egaliter masih panjang, hal itu harus dilihat sebagai sesuatu yang memprihatinkan seluruh bangsa Indonesia. Karena watak cita-cita politik Islam yang universal itu, pendekatannya pun harus bersifat integratif, dengan melibatkan seluruh kekuatan bangsa.

Dengan demikian, cita-cita untuk menegakkan nilai-nilai demokrasi hendaknya dilakukan di dalam kerangka sistem politik yang ada. ${ }^{15}$ Berpangkal tolak dari definisi dan cita-cita politik dan kepemimpinan Islàm, strategi perjuangan politik is- lam yang dikembangkan lebih bersifat inklusif, integratif, dan diversifikatif yang dirumuskan dalam kerangka cita-cita masyarakat Indonesia secara keseluruhan. Dapat dikatakan bahwa agenda ini meliputi soal-soal demokratisasi, toleransi politik dan agama, egalitarianisme sosial-ekonomi dan partisipasi politik. Hal ini semua menunjukkan adanya sebuah transformasi yang cukup berarti dalam pemikiran dan praktek politik Islam. Semua itu, baik pada tatanan teologis, cita-cita politik, dan strategi pendekatannya, ditujukan! untuk menghadirkan sebuah sintesa yang memungkinkan antara Islam dan politik. Dalam konteks yang lebih empirik, intelektualisme dan aktivisme politik dikembangkan untuk menghadirkan sebuah Islam politik yang lebih inklusif dan integratif dalam hubungannya dengan konstruk negara Indonesia yang ada.

\section{Penutup}

Wacana untuk menjalin kerjasama politik atau koalisi antarkekuatan politik sah-sah saja dilakukan oleh partai politik. Apalagi melihat arah dan kecenderungan dukungan massa dalam pemilu 2004 yang menyebar, kerjasama politik atau .koalisi merupakan keniscayaan. Akan tetapi, yang lebih penting adalah melihat seberapa besar motivasi itu terbangun, apakah hanya semata-mata karena alasan dan pertimbangan politik praktis saja atau

${ }^{13}$ Robert N.. Bellah, . Beyond Belief : Essays on Religion in a Post-Traditionalist World. (Berkeley dan Los Angeles: University of California Press. 1991), hlm. 151.

14 Bosco Carvalo dan Dasrizal. (Ed.). Aspirasi Umat Islam Indonesia. (Jakarta : Leppenas, 1983).

${ }^{15}$ Munawir Sjadzali. Islam dan Tata Negara Ajaran, Sejarah dan Pemikiran. (Jakarta: UI-Press. 1990). 
kekuasaan atau memang sudah dibangun dengan mempertimbangkan alasan-alasan yang rasional kalkulatif dan idealitas.

Indonesia ini sesungguhnya akan mudah dikelola secara bersama-sama sesuai dengan kompetensinya masingmasing. Artinya, di tengah membuncahnya perbedaan di antara kita, jangan pernah melupakan kerjasama dan bersama-sama antarsemua komponen di dalam masyarakat. Jika ini dapat berlangsung dengan baik, tidak berlebihan bahwa krisis ini akan lebih mudah kita atasi. ${ }^{16}$

Untuk mewujudkan cita-cita kepemimpinan politik muslim di Indonesia pasca pemilu 2004 membutuhkan pendekatan substantif yang bersifat integratif dan diversifikatif dengan melibatkan seluruh kekuatan bangsa. Di samping itu, untuk mencapai cita-cita tersebut, strategi perjuangan yang dikembangkan hendaklah lebih bersifat inklusif, integratif dan diversifikatif yang diformulasikan dalam kerangka cita-cita masyarakat Indonesia secara keseluruhan.

Untuk mendukung ke arah terwujudnya - cita-cita seluruh bangsa Indonesia, kriteria pemimpin bangsa yang dibutuhkan adalah pemimpin yang mempunyai sikap inklusif pluralis dan dialogis. Namun demikian, sampai saat ini, Indonesia belum lagi mempunyai pemimpin berjiwa seperti itu. Yang ada sekarang ini adalah kebanyakan para pemimpin yang oportunistik dan menggunakan segala cara untuk meraih kekuasaan dan kedudukan yang terhormat bagi diri dan kelompoknya sendiri. Harapan semua pihak tentunya tidak lain agar pemilu 2004 dapat menghasilkan para pemimpin bangsa yang berjiwa dan bersikap inklusif pluralis dan dialogis serta mampu membawa bangsa ini keluar dari krisis multidimensional.

\section{Daftar Pustaka}

Bellah, Robert N., 1991. Beyond Belief : Essays on Religion in a Post-Traditionalist World. Berkeley dan Los Angeles: University of California Press.

Carvalo, Bosco dan Dasrizal. (Ed.), 1983. Aspirasi Umat Is/am Indonesia. Jakarta: Leppenas.

Effendy, Bahtiar, 1995. "Islam dan Negara Transformasi Pemikiran dan Praktek Politik Islam di Indonesia." Dalam Prisma 5 Mei 1995. Jakarta:LP3ES.

Effendy, Bahtiar, 1998. Islam dan Negara: Transformasi Pemikiran dan Praktik. Politik Islam di Indonesia. Jakarta : Paramadina dan Ibnu Sina

Haryatmoko,2003.,Etika Politik dan Kekuasaan. Jakarta: Kompas.

Ma'arif, Ahmad Syafili, 1995. Membumikan Islam. Yogyakarta: Pustaka Pelajar.

Madjid,. Nurcholish, 1998." Mencari AkarAkar Islam Bagi Pluralisme Modern :Pengalaman Indonesia", dalam Mark R.Woodward (Ed.). Jalan Baru /slam Memetakan Paradigma Mutakhir islam Indonesia terjemahan dari jududl asli Toward A New Paradigm : Recent Developments in Indonesian islamic Thought oleh Jhsan Ali - Fauzi. Bandung: Mizan

Madjid, Nurcholish, 2003. Islam Agama Kemanusiaan Membangun Tradisi

${ }^{16} \mathrm{H}$. Pontjo Sutowo," Pemilu 2004 dan Problem Kepemimpinan Bangsa", dalam Republika, Jumat, 2 April 2004 Opini, hlm.4. 
Topik: Kepemimpinan Nasional Pasca Pemilu 2004

dan Visi Baru Islam Indonesia. Jakarta: Paramadina.

Mardiasmo, "Sistem Pengukuran Kinerja Sektor Publik: Telaah Kritis Terhadap Kebutuhan Pengukuran Kinerja Pemerintah Daerah", dalam Jurnal IImu-IImu Sosial Unisia No.46/XXVI III/2002, Yogyakarta: Unisia.

Saleh, Asmar Oemar.2003. "Kriteria Presiden Masa Depan", Rabu, 15 Oktober 2003, Jakarta:Republika.

Sjadzali, Munawir, 1990. Islam dan Tata Negara Ajaran, Sejarah dan Pemikiran. Jakarta: UI-Presș.

Sutowo, H. Pontjo, 2004. "Pemilu 2004 dan Problem
Kepemimpinan
Bangsa",Opini,Jumat, 2. April 2004.Jakarta:Republika.

Syamsuddin, M. Din,2001. Islam dan Politik Era Orde Baru. Pengantar Bahtiar Effendy. Jakarta :Logos.

Thaba, Abdul Azis, 1996. Islam dan Negara Dalam Politik Orde Baru. Jakarta : Gema Insani Press.

Wahid, Abdurrahman, 1984." Massa Islam dalam Kehiodupan Bernegara dan Berbangsa", dalam Prisma, Edisi Extra, 1984, Jakarta:LP3ES.

Wahid, Abdurrahman, 1985. "Merumuskan Hubungan Ideologi Nasional dan Ajaran Agama", Aula Mei 1985. 